\title{
Geochemical Soil Survey for Base and Precious Metals in Dagbala-Atte District, Southwestern Nigeria
}

\author{
Mohammed Olatoye Adepoju \\ Department of Applied Geology, The Federal University of Technology, Akure, Nigeria \\ Email: moadepoju@futa.edu.ng
}

How to cite this paper: Adepoju, M.O. (2019) Geochemical Soil Survey for Base and Precious Metals in Dagbala-Atte District, Southwestern Nigeria. International Journal of Geosciences, 10, 141-159. https://doi.org/10.4236/ijg.2019.102009

Received: December 29, 2018

Accepted: February 12, 2019

Published: February 15, 2019

Copyright $\odot 2019$ by author(s) and Scientific Research Publishing Inc. This work is licensed under the Creative Commons Attribution International License (CC BY 4.0).

http://creativecommons.org/licenses/by/4.0/

\begin{abstract}
Geochemical survey of residual soils was undertaken in Dagbala-Atte District of Igarra Schist Belt, southwestern Nigeria to explore for base and precious metals $(\mathrm{Cu}, \mathrm{Pb}, \mathrm{Zn}, \mathrm{Au}$ and $\mathrm{Ag})$. It involved sampling residual soil from 49 sites in a grid pattern; analyzing the soil samples for the base and precious metals and other commonly associated elements including $\mathrm{As}, \mathrm{Cd}, \mathrm{Fe}, \mathrm{Hg}$ and $\mathrm{Sb}$; subjecting the geochemical data generated to statistical analysis; and preparing the geochemical distribution map of the district for each element. On the basis of the multivariate statistical analysis (correlation matrix and factor analysis) of the soil geochemical data, three mineralization types were inferred to be present in the district. The suspected types of mineralization consist of: 1) $\mathrm{Cu}-\mathrm{Pb}-\mathrm{Zn}-\mathrm{Ag}$ mineralization with associated $\mathrm{As}, \mathrm{Hg}$, $\mathrm{Sb}$ and Fe; 2) $\mathrm{Au}-\mathrm{Cu}$ mineralization with associated $\mathrm{As}$; and 3) minor $\mathrm{Hg}$-bearing $\mathrm{Au}-\mathrm{Pb}$ mineralization. With the aid of the elemental geochemical distribution maps, the suspected mineralization was linked to rock types from which the sampled residual soils were apparently derived. Hence, the suspected $\mathrm{Cu}-\mathrm{Pb}-\mathrm{Zn}-\mathrm{Ag}$ mineralization is linked to the quartz-biotite schist at the southwestern part of the district while the suspected $\mathrm{Au}-\mathrm{Cu}$ mineralization is located on the silicified sheared rock at the northern and southern parts and the minor $\mathrm{Hg}$-bearing $\mathrm{Au}-\mathrm{Pb}$ mineralization within the granitic gneiss at the northeastern and eastern areas of the district. Based on the foregoing findings, it is recommended that lithogeochemical survey for the base and precious metals should be done in the area.
\end{abstract}

\section{Keywords}

Dagbala-Atte District, Factor Analysis, Geochemical Distribution Map, Mineralization 


\section{Introduction}

On the basis of high potential for metallic mineralization of the Paleoproterozoic Schist Belts in northern Nigeria [1] [2] [3] [4] which are similar to the Igarra Schist Belt in southern Nigeria, the Postgraduate Mineral Exploration Research Group of the Applied Geology Department, the Federal University of Technology, Akure initiated a geochemical exploration program of the Igarra Schist Belt area. The program commenced with regional stream sediment survey which detected anomalous concentrations of base and precious metals among others around Dagbala and Atte areas [5] [6] [7]. The next step in the planned geochemical survey of the belt is to follow up these stream sediment anomalies by tracing them to their possible land sources particularly because environmental contamination around Dagbala and Atte has been ruled out based on pollution studies carried out by [8] [9] in the area. The follow-up of the stream sediment anomalies is based on the notion that the stream sediments are derived from the soil by processes of erosion and deposition in the stream beds. Hence, the present aspect of the research program is to conduct a soil geochemical survey of the Dagbala-Atte area for base and precious metals which showed up in anomalous values in the stream sediments of the area [6] [7]. Similar surveys using residual soil as a sampling medium have been carried out by other workers particularly because the results of such surveys are much easier to interpret in terms of the source of the elements [10]-[15]. The principal objective of this study therefore is to locate the possible source $(\mathrm{s})$ of the metals $(\mathrm{Cu}, \mathrm{Pb}, \mathrm{Zn}, \mathrm{Au}$ and $\mathrm{Ag})$ in the residual soils of the study area.

\section{Geological Setting of the Study Area}

Dagbala-Atte District lies within latitude $7^{\circ} 10^{\prime} \mathrm{N}$ and $7^{\circ} 21^{\prime} \mathrm{N}$ and longitude $6^{\circ} 09^{\prime} \mathrm{E}$ and $6^{\circ} 17^{\prime} \mathrm{E}$ in the northern part of Edo State, Nigeria (Figure 1 and Figure 2) and covers an area of about $285 \mathrm{~km}^{2}$ within the Igarra Schist Belt, which is surrounded by the older Basement Complex rocks believed to be of Archean to Paleoproterozoic age [16] [17]. Low-grade metasediments commonly described as the Younger metasediments [18] or Newermetasediments [19] dominate the schist belt. These metasediments consist essentially of a deformed package of pelitic to semi-peliticschists, marbles, calc-silicate gneiss, quartzites and polymicticmetaconglomerates [20] [21] [22] [23]. Both the Younger metasediments and the older basement rocks (i.e. the gneisses and migmatites) were intruded by the Pan African granites (also known as the Older Granites) represented by the lgarra batholith. Minor felsic and mafic intrusives, including pegmatites, aplite, syenite, lamprophyre and dolerite cross-cut the Pan African granites and the pre-existing rocks.

In the Dagbala-Atte District the rock suites are divisible into the eastern portion dominated by granite gneiss and the western part composed mainly of the Younger metasediments with both portions separated by a narrow zone of silicified, sheared rock (Figure 3) [24]. The metasedimentary package consists 

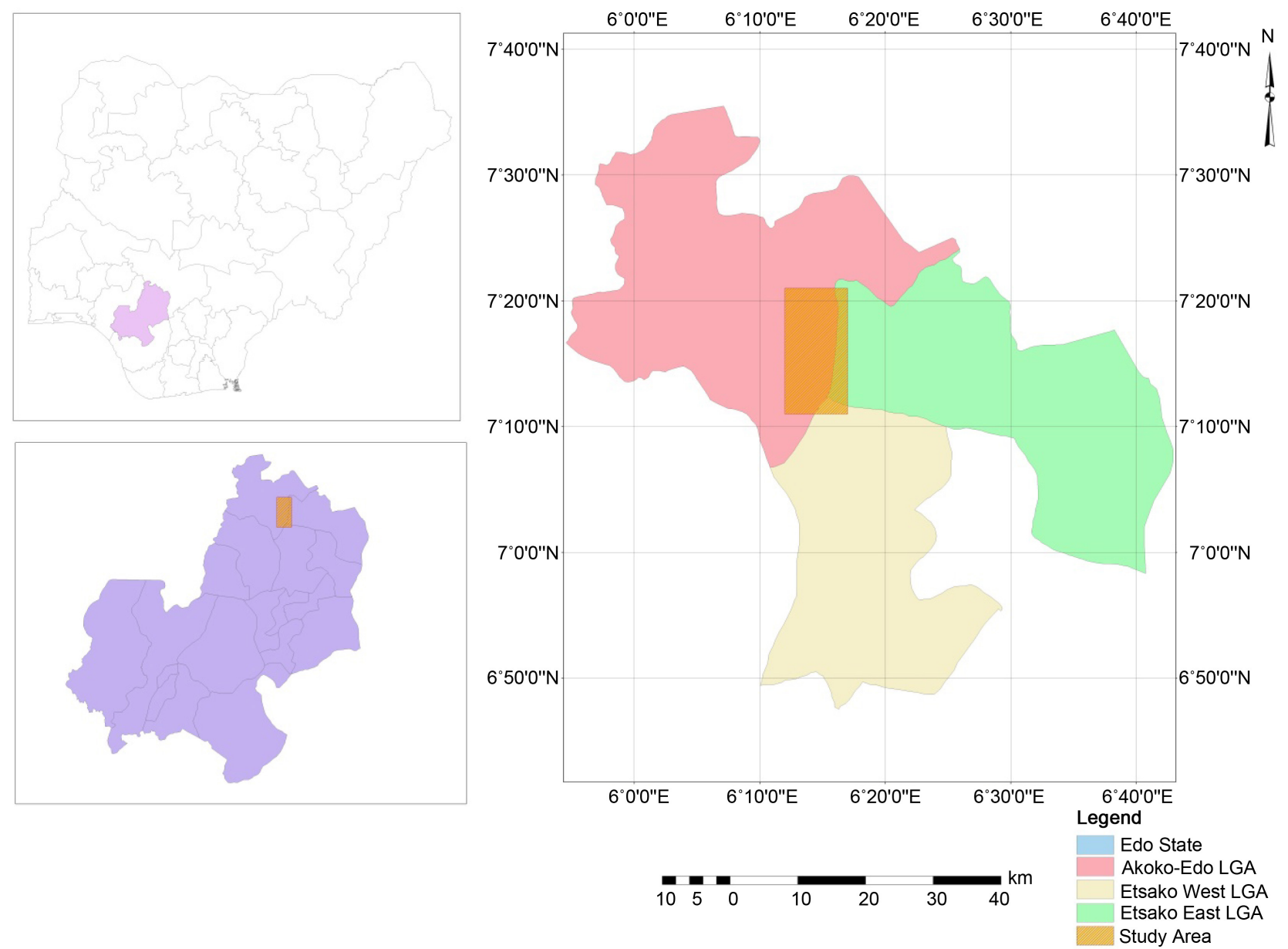

Figure 1. Location map of the study area. Insets: map of Nigeria showing Edo state and map of Edo state showing the location of Dagbala-Atte district.

predominantly of quartz-biotite, garnet-biotite and mica schists with minor metaconglomerate, quartzites and marble. Both the metasediments and granite gneiss are intruded by porphyritic Pan African granite. All the rock types are affected by intense weathering to varying degrees under the prevailing humid tropical climatic conditions producing ubiquitous residual soil profiles.

\section{Methodology}

The study entailed three stages as follows: 1) sampling of B-horizon soils from the Dagbala-Atte District of $285 \mathrm{~km}^{2}$; 2) geochemical analysis of the soil samples so as to determine the contents of the metals under consideration; and 3) data analysis, which involved qualitative and quantitative analyses.

\subsection{Soil Sampling}

The study area was first gridded into approximately $2 \times 3 \mathrm{~km}$ portions on a topographic map of the area. This was followed by cutting traverse lines on the field to demarcate the grids (Figure 2 and Figure 3). Soil sampling was done on each grid by driving a 1-meter auger some $20-30 \mathrm{~cm}$ into the ground after 


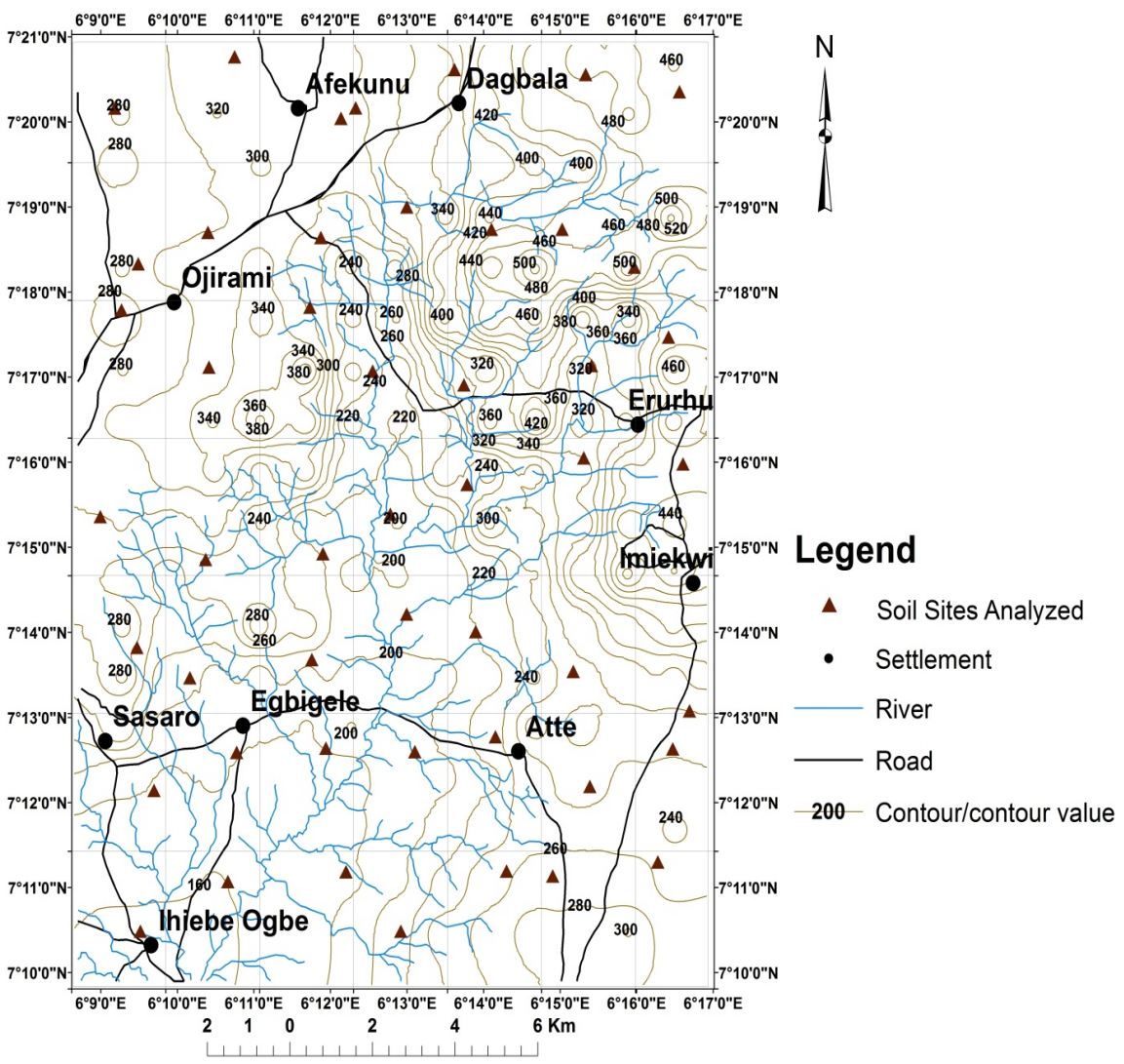

Figure 2. Topographic map of Dagbala-Atte district showing the localities of forty nine soil samples employed for this study.

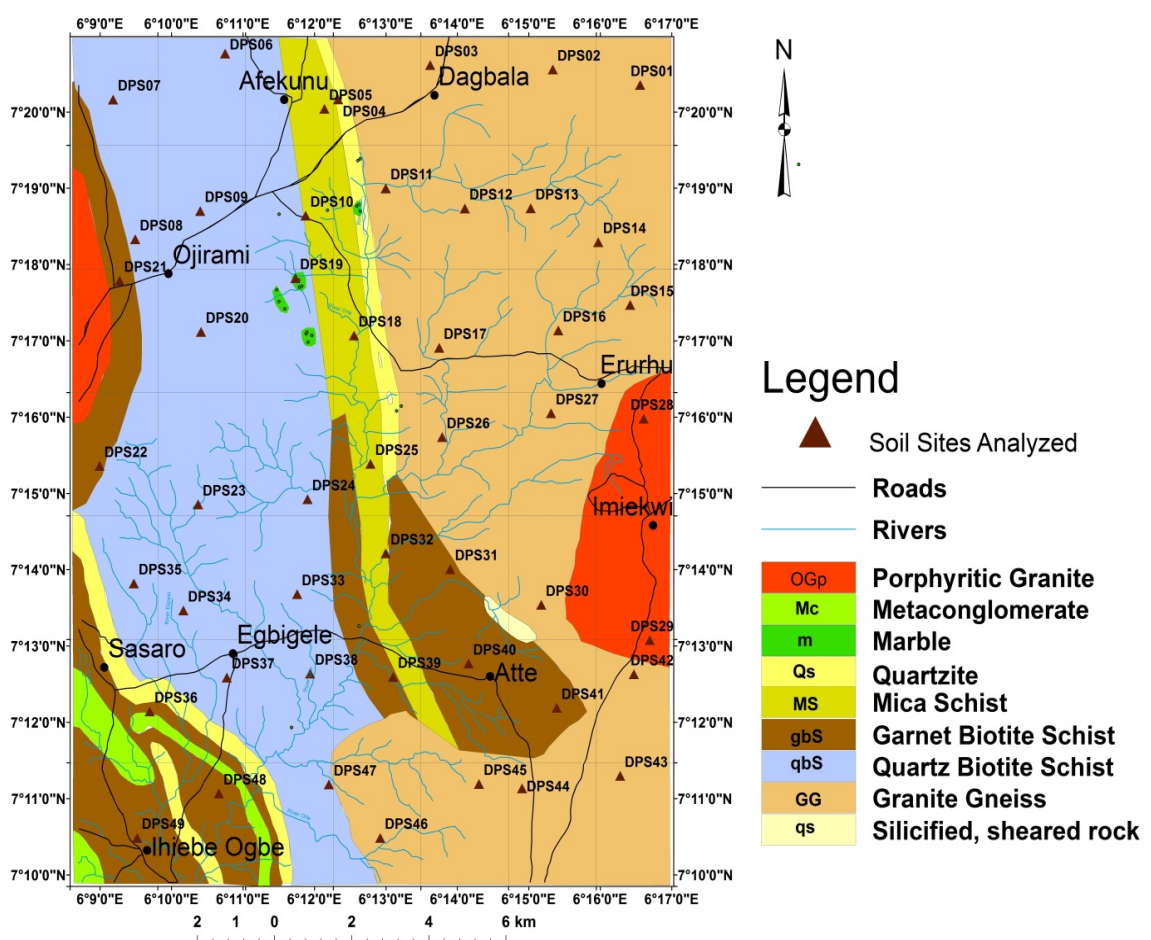

Figure 3. Geological map of Dagbala-Atte district showing the locations of the forty-nine soil samples in a grid pattern (Adapted from [24]). 
removing the sandy top soil at every site marked by a labeled stake to ensure adequate penetration into the B-horizon which is preferred in most soil surveys owing to its high accumulation of trace elements [25]. The samples were carefully hammered out of the auger into pre-labeled baft cloth bags. Appropriate care was taken to avoid contamination during the sampling operation by cleaning the auger with water and ethanol after occupying each grid. A total of 49 samples were collected and transported to the laboratory. A global positioning system (GPS) receiver was employed for accurate sample site location on the base map. A particular attention was paid to the soil profile being sampled because the target was to sample residual soil, i.e. in situ soil profile, while transported soil was avoided.

\subsection{Geochemical Analysis of the Soil Samples}

The soil samples were first air dried at room temperature for four weeks, after which they were disaggregated prior to sieving with stainless steel screen of 200 microns size. The fraction passing through the sieve size was then pulverized to less than 75 microns using a porcelain mortar and pestle. All these were done with special care to avoid cross contamination. After the foregoing sample preparation in Nigeria, the soil samples were analyzed at Acme Laboratories, Vancouver, Canada using the following procedures.

Half of a gram $(0.5 \mathrm{~g})$ of each of the pulverized soil samples was weighed into graduated test tubes and $5 \mathrm{ml}$ of 1:1:1 mixture of $\mathrm{HCl}-\mathrm{HNO}_{3}-\mathrm{H}_{2} \mathrm{O}$ (modified aqua regia) was added to the samples. The mixture was heated at $95^{\circ} \mathrm{C}$ for one hour. After the mixture for each sample had cooled down, it was filtered and the leached solution obtained was diluted with ultra-pure water to $10 \mathrm{ml}$. The resulting solutions for all the samples were subjected to elemental analysis using an Inductively-Coupled Plasma Mass Spectrophotometer (ICP-MS) at the Acme Laboratories, Canada. The analytical results of eleven elements of interest, namely, $\mathrm{Ag}$, As, $\mathrm{Au}, \mathrm{Cd}, \mathrm{Cu}, \mathrm{Fe}, \mathrm{Hg}, \mathrm{Mn}, \mathrm{Pb}, \mathrm{Sb}$ and $\mathrm{Zn}$, are presented in Table 1.

\subsection{Data Analysis}

The analytical results of the elements were subjected to quantitative statistical analysis and qualitative treatment. The quantitative statistical analysis comprised some univariate and multivariate statistics while the qualitative treatment involved plotting geochemical distribution map for the elements. Univariate statistics used here include histograms and box plots of both raw and log-transformed data. These plots are often useful when grouped together as they provide different ways of summarizing data and are necessary to reasonably establish the threshold values leading to the isolation of anomalous concentrations of the elements in the soils of the study area. The multivariate statistics in this paper consisted of correlation matrix and factor analysis.

\subsubsection{Statistical Analysis of Geochemical Data}

Quantitative statistical analysis employed in this study is widely used as a useful 
Table 1. Raw concentrations of trace-elements in soils of Dagbala-Atte district. Ag, Au and $\mathrm{Hg}$ in ppb, Fe in \% and other elements in ppm.

\begin{tabular}{|c|c|c|c|c|c|c|c|c|c|c|c|c|c|}
\hline HMS & Longitude & Latitude & $\mathrm{Ag}$ & As & $\mathrm{Au}$ & $\mathrm{Cd}$ & $\mathrm{Cu}$ & $\mathrm{Fe}$ & $\mathrm{Hg}$ & $\mathrm{Mn}$ & $\mathrm{Pb}$ & $\mathrm{Sb}$ & $\mathrm{Zn}$ \\
\hline S01 & 6.27601 & 7.33925 & 12 & 0.6 & 1.2 & 0.01 & 17.31 & 1.9 & 37 & 80 & 9.41 & 0.03 & 13.4 \\
\hline S02 & 6.25559 & 7.34263 & 4 & 0.7 & 1.3 & 0.01 & 4.72 & 0.87 & 18 & 480 & 8.99 & 0.04 & 8.6 \\
\hline $\mathrm{S} 03$ & 6.22703 & 7.34360 & 6 & 0.9 & 1.7 & 0.01 & 11.81 & 2.64 & 23 & 381 & 14.89 & 0.03 & 18.6 \\
\hline S04 & 6.20553 & 7.33612 & 10 & 5.1 & 4.8 & & 10.65 & 2.64 & 32 & 263 & 10.05 & 0.06 & 14.5 \\
\hline S05 & 6.20233 & 7.33403 & 3 & 0.7 & 2.3 & & 5.15 & 0.83 & 9 & 120 & 4.67 & 0.02 & 8 \\
\hline S06 & 6.17917 & 7.34610 & 7 & 1.2 & 2.1 & & 9.97 & 2.12 & 26 & 158 & 8.93 & 0.04 & 15.8 \\
\hline S07 & 6.15307 & 7.33607 & & 0.6 & 8.3 & 0.01 & 3.21 & 0.7 & 15 & 107 & 6.24 & 0.03 & 11.1 \\
\hline S08 & 6.15820 & 7.30553 & 6 & 0.3 & 1.7 & & 1.43 & 0.37 & 7 & 230 & 4.35 & & 2.2 \\
\hline S09 & 6.17338 & 7.31172 & & 0.3 & 0.9 & & 1.32 & 0.12 & 10 & 16 & 1.99 & & 2.3 \\
\hline S10 & 6.19797 & 7.31070 & 5 & 0.7 & 5.6 & 0.03 & 21.66 & 2.83 & 10 & 296 & 10.47 & 0.02 & 56.5 \\
\hline S11 & 6.21667 & 7.31667 & 4 & 214.5 & 12.5 & & 78.9 & 4.43 & 15 & 21 & 10.74 & 0.11 & 31 \\
\hline S12 & 6.23509 & 7.31228 & 16 & 0.8 & 0.5 & 0.06 & 7.27 & 1.12 & 109 & 673 & 19.23 & 0.02 & 16.1 \\
\hline S13 & 6.25047 & 7.31230 & 9 & 0.6 & 0.5 & 0.05 & 11.8 & 1.46 & 22 & 279 & 8.21 & 0.04 & 13.8 \\
\hline S14 & 6.26623 & 7.30491 & 19 & 0.5 & 1.3 & & 5.69 & 1.49 & 24 & 116 & 8.44 & & 25.3 \\
\hline S15 & 6.27367 & 7.29119 & 58 & 1.2 & 9.8 & 0.05 & 11.8 & 3.6 & 26 & 459 & 24.99 & 0.05 & 68 \\
\hline S16 & 6.25689 & 7.28561 & 23 & 1.9 & 3.5 & & 15.38 & 5.49 & 44 & 427 & 19.52 & 0.05 & 36.1 \\
\hline S17 & 6.22911 & 7.28183 & 6 & 0.6 & 2.7 & 0.01 & 32.05 & 2.55 & 10 & 315 & 2.65 & & 41.5 \\
\hline S18 & 6.20923 & 7.28452 & 23 & 2.4 & 8.3 & 0.03 & 14.38 & 2.1 & 19 & 312 & 7.1 & 0.03 & 40.7 \\
\hline S19 & 6.19558 & 7.29703 & 27 & 3.5 & 1.8 & 0.02 & 14.86 & 2.21 & 7 & 356 & 8.12 & 0.06 & 46.3 \\
\hline S20 & 6.17358 & 7.28531 & 13 & 0.3 & 0.5 & & 3.57 & 0.35 & & 37 & 4.35 & & 6.8 \\
\hline S21 & 6.15455 & 7.29648 & 18 & 0.5 & 0.7 & 0.03 & 10.91 & 1.17 & 10 & 386 & 8.23 & 0.05 & 29.8 \\
\hline S22 & 6.14990 & 7.25602 & 15 & 0.5 & & 0.02 & 4.28 & 0.66 & 7 & 210 & 4.4 & & 6.6 \\
\hline S23 & 6.17286 & 7.24761 & 22 & 1.9 & 1.2 & 0.02 & 24.85 & 3.34 & 15 & 502 & 13.6 & 0.05 & 75.2 \\
\hline S24 & 6.19840 & 7.24875 & 29 & 0.7 & 2.2 & 0.02 & 10.86 & 1.8 & 28 & 402 & 8.53 & 0.08 & 29.6 \\
\hline S25 & 6.21308 & 7.25647 & 5 & 0.1 & 0.7 & & 3 & 0.52 & 13 & 264 & 5.7 & & 4.5 \\
\hline S26 & 6.22980 & 7.26231 & 16 & 0.7 & & & 20.16 & 2.5 & 23 & 496 & 9.01 & 0.03 & 36.9 \\
\hline S27 & 6.25521 & 7.26753 & 14 & 0.8 & 0.6 & 0.06 & 10.87 & 2.16 & 34 & 893 & 16.5 & 0.05 & 59 \\
\hline S28 & 6.27683 & 7.26634 & 28 & 0.9 & 2.6 & 0.03 & 10.8 & 8.12 & 35 & 983 & 20.41 & 0.02 & 161.5 \\
\hline S29 & 6.27823 & 7.21795 & 14 & 2 & & & 12.05 & 3.97 & 14 & 374 & 8.94 & 0.38 & 164.1 \\
\hline S30 & 6.25292 & 7.22567 & 26 & 0.8 & 6.6 & & 12.9 & 2.2 & 29 & 268 & 14.88 & 0.03 & 61 \\
\hline S31 & 6.23168 & 7.23347 & 19 & 1.3 & 3.8 & 0.02 & 14.43 & 2.72 & 32 & 286 & 16.03 & 0.05 & 33.4 \\
\hline S32 & 6.21665 & 7.23692 & 6 & 0.5 & 1.4 & & 24.98 & 3.43 & 13 & 288 & 11.9 & 0.02 & 45.6 \\
\hline S33 & 6.19598 & 7.22800 & 19 & 0.9 & 1.1 & 0.02 & 25.79 & 2.29 & 10 & 483 & 11.19 & 0.07 & 38.4 \\
\hline S34 & 6.16945 & 7.22443 & 155 & 3.5 & 0.8 & 0.04 & 21.76 & 2.79 & 18 & 658 & 15.92 & 0.23 & 181.4 \\
\hline S35 & 6.15790 & 7.23035 & 41 & 4 & 0.7 & 0.04 & 31.36 & 3.6 & 32 & 804 & 16.17 & 0.22 & 47.4 \\
\hline
\end{tabular}




\begin{tabular}{rrrrrrrrrrrrrrr}
\multicolumn{1}{l}{ Continued } \\
\hline S36 & 6.16160 & 7.20237 & 10 & 0.4 & 0.4 & & 8.46 & 1.19 & 6 & 208 & 8.59 & 0.02 & 15.4 \\
S37 & 6.17962 & 7.20980 & 10 & 0.5 & 0.8 & & 4.32 & 0.86 & 9 & 306 & 9.2 & 0.04 & 7.3 \\
S38 & 6.19903 & 7.21065 & 140 & 17.4 & 1.3 & 0.03 & 19.12 & 12.33 & 41 & 127 & 15.95 & 0.34 & 358.8 \\
S39 & 6.21840 & 7.20993 & 27 & & 0.4 & & 20.48 & 2.26 & 17 & 382 & 11.71 & 102.5 \\
S40 & 6.23597 & 7.21285 & 10 & 0.5 & 0.4 & & 8.02 & 1.27 & 13 & 213 & 5.6 & 0.02 & 20.8 \\
S41 & 6.25653 & 7.20315 & 11 & 1.4 & & & 6.85 & 1.51 & 19 & 296 & 18.83 & 0.05 & 66.1 \\
S42 & 6.27455 & 7.21050 & 24 & 0.6 & 1.2 & 0.02 & 33.22 & 2.9 & 23 & 1159 & 17.25 & 0.05 & 104.4 \\
S43 & 6.27132 & 7.18831 & 17 & 0.8 & 5.9 & & 13.61 & 2.13 & 22 & 512 & 14.14 & 0.04 & 106.2 \\
S44 & 6.24842 & 7.18557 & 15 & 0.5 & & 0.01 & 6.27 & 1.62 & 26 & 451 & 20.2 & 0.04 & 167.7 \\
S45 & 6.23840 & 7.18655 & 18 & 2.6 & 1.4 & & 11.3 & 5.84 & 27 & 302 & 16.28 & 0.08 & 98.9 \\
S46 & 6.21537 & 7.17475 & 43 & 1 & 0.4 & & 7.69 & 2.39 & 36 & 493 & 26.94 & 0.03 & 145.5 \\
S47 & 6.20342 & 7.18643 & 40 & 2.3 & 0.5 & 0.03 & 11.68 & 2.09 & 50 & 646 & 12.41 & 0.24 & 132.3 \\
S48 & 6.17772 & 7.18448 & 7 & 0.7 & & & 11.72 & 1.72 & 12 & 254 & 9.09 & 0.07 & 18.9 \\
S49 & 6.15867 & 7.17477 & 8 & 0.4 & 0.8 & 0.01 & 9.22 & 1.12 & 10 & 289 & 5.08 & 0.05 & 77.6 \\
\hline
\end{tabular}

and necessary technique in interpretation of geochemical data [5] [7] [26] [27] [28] [29] [30]. Therefore, histograms, box plots, correlation matrix and factor analysis were constructed using the analytical results with the help of a software package - Minitab-16 in a DELL Inspiron 5521 Laptop computer. Both the histogram and box plots were done using the raw and log-transformed geochemical data. A summary of the basic statistics and other parameters derived from the box plots (1st quartile, 3rd quartiles and interquartile range) is tabulated for the 11 elements involved in the present study (Table 2). The table also includes threshold values calculated using formulae - Mean $+2^{\star}$ Standard deviation and Q3 + 1.5* interquartile range, for the logarithmically transformed data since the elements in the soils of the study area are log-normally distributed. However, the threshold values computed from formula Q3 +1.5 interquartile range is adopted for this study because it gave relatively low values which enhance the number of anomalous sites that were recognized in this study.

\subsubsection{Plotting of Geochemical Distribution Map}

The distribution maps of the elements in the soils of the district based on the raw data in Table 1 and the soil sample location map of the study area (Figure 2 and Figure 3) drawn using Arc-GIS 10.4.1 program in a DELL Inspiron 5521 Laptop computer have been used to explain the distribution of the various elements in the soils of the study area.

\section{Results and Discussion}

\subsection{Histograms}

The histogram is one of the most popular graphical means of displaying distribution since it reflects the shape similar to theoretical frequency distributions. 
Table 2. Summary statistics for residual soils in Dagbala-Atte district, Nigeria.

\begin{tabular}{cccccccccccc}
\hline Elements & $\begin{array}{c}\text { Min. } \\
\text { Conc. }\end{array}$ & $\begin{array}{c}1^{\text {st }} \\
\text { Quartile } \\
\left(\mathrm{Q}_{1}\right)\end{array}$ & Median & $\begin{array}{c}\text { Max. } \\
\text { Conc. }\end{array}$ & $\begin{array}{c}3^{\text {rd }} \\
\text { Quartile } \\
\left(\mathrm{Q}_{3}\right)\end{array}$ & $\begin{array}{c}\text { No of } \\
\text { samples } \\
\text { where } \\
\text { detected }\end{array}$ & $\begin{array}{c}\text { Geometric } \\
\text { Mean } \\
(\mathrm{X})\end{array}$ & $\begin{array}{c}\text { Standard } \\
\text { Deviation } \\
(\mathrm{S})\end{array}$ & $\begin{array}{c}\text { Threshold } \\
\text { Log }^{-1} \\
(\mathrm{X}+2 \mathrm{~S})\end{array}$ & $\begin{array}{c}\text { Threshold } \\
\text { Log }^{-1} \\
\left(\mathrm{Q}_{3}+1.5\right. \\
\left(\mathrm{Q}_{3}-\mathrm{Q}_{1}\right)\end{array}$ \\
\hline $\mathrm{Ag}$ & 0.477 & 0.903 & 1.176 & 2.190 & 1.380 & 47 & 1.174 & 0.366 & 80.568 & 1.763 \\
$\mathrm{As}$ & -1 & 1.020 & -0.126 & 2.331 & 1.775 & 48 & 0.008 & 0.513 & 10.820 & 3.5 \\
$\mathrm{Au}$ & -0.398 & 0.7 & 0.114 & 1.097 & 2.7 & 43 & 0.180 & 0.423 & 10.645 & 5.6 \\
$\mathrm{Cd}$ & -2 & 0.01 & -1.699 & -1.222 & 0.033 & 26 & -1.649 & 0.261 & 0.075 & 0.06 \\
$\mathrm{Cu}$ & 0.121 & 7.06 & 1.067 & 1.897 & 18.215 & 49 & 1.029 & 0.341 & 51.486 & 33.22 \\
$\mathrm{Fe}$ & -0.921 & 1.18 & 0.328 & 1.091 & 2.81 & 49 & 0.265 & 0.356 & 9.467 & 4.43 \\
$\mathrm{Hg}$ & 0.778 & 10.5 & 1.279 & 2.037 & 28.75 & 48 & 1.272 & 0.265 & 63.264 & 50 \\
$\mathrm{Mn}$ & 1.204 & 221.5 & 2.486 & 3.064 & 481.5 & 49 & 2.452 & 0.374 & 1589.24 & 804 \\
$\mathrm{~Pb}$ & 0.299 & 8.165 & 1.002 & 1.430 & 15.99 & 49 & 1.003 & 0.244 & 30.978 & 26.94 \\
$\mathrm{Sb}$ & -1.699 & 0.03 & -1.301 & -0.420 & 0.065 & 41 & -1.301 & 0.337 & 0.236 & 0.11 \\
$\mathrm{Zn}$ & 0.342 & 14.95 & 1.567 & 2.555 & 76.4 & 49 & 1.520 & 0.506 & 340.158 & 167.7 \\
\hline
\end{tabular}

Histograms plotted on raw data show positive skewness of the elements in varying degrees while those plotted on the log-transformed data display no skewness, which indicates that the distribution of the elements are log-normal. Examples of these two sets of histograms are presented in Figure 4(a) for histograms plot on raw data and Figure 4(b) for those plots on log-transformed data. Most of the raw data histograms show breaks in distribution, which might be interpreted as revealing mixtures of populations. Breaks in distribution occur at $75 \mathrm{ppb}$ for $\mathrm{Ag}, 20 \mathrm{ppm}$ for As, $37.5 \mathrm{ppm}$ for $\mathrm{Cu}, 1.75 \%$ for $\mathrm{Fe}, 70 \mathrm{ppm}$ for $\mathrm{Hg}, 0.12 \mathrm{ppm}$ for $\mathrm{Sb}$ and $200 \mathrm{ppm}$ for $\mathrm{Zn}$. However, the log-transformed data histograms show breaks in distribution for only As and Cd.

\subsection{Box Plots}

The box plot is a method used to display some statistical parameters in a graphical form [31]. Provided the scale of presentation is reasonable, the box plot provides a fast visual estimate of the frequency distribution. Examples of the dispersion box plots of the trace metals based on both the raw and log-transformed data are presented in Figure 5(a) and Figure 5(b), respectively. The raw data box plots (Figure 5(a)) show longer whiskers above the mean and shorter ones below it. This implies that most of the values of the elements greatly depart from the mean, which is also an indication of the extreme variability of geochemical data. This trend in any data set indicates non-normal situation. In the case of the log-transformed dispersion box plots (Figure 5(b)) a more refined dataset resulted with both the maximum and minimum values evenly distributed about the mean value. This provided a data set with a smaller and more stable variance 

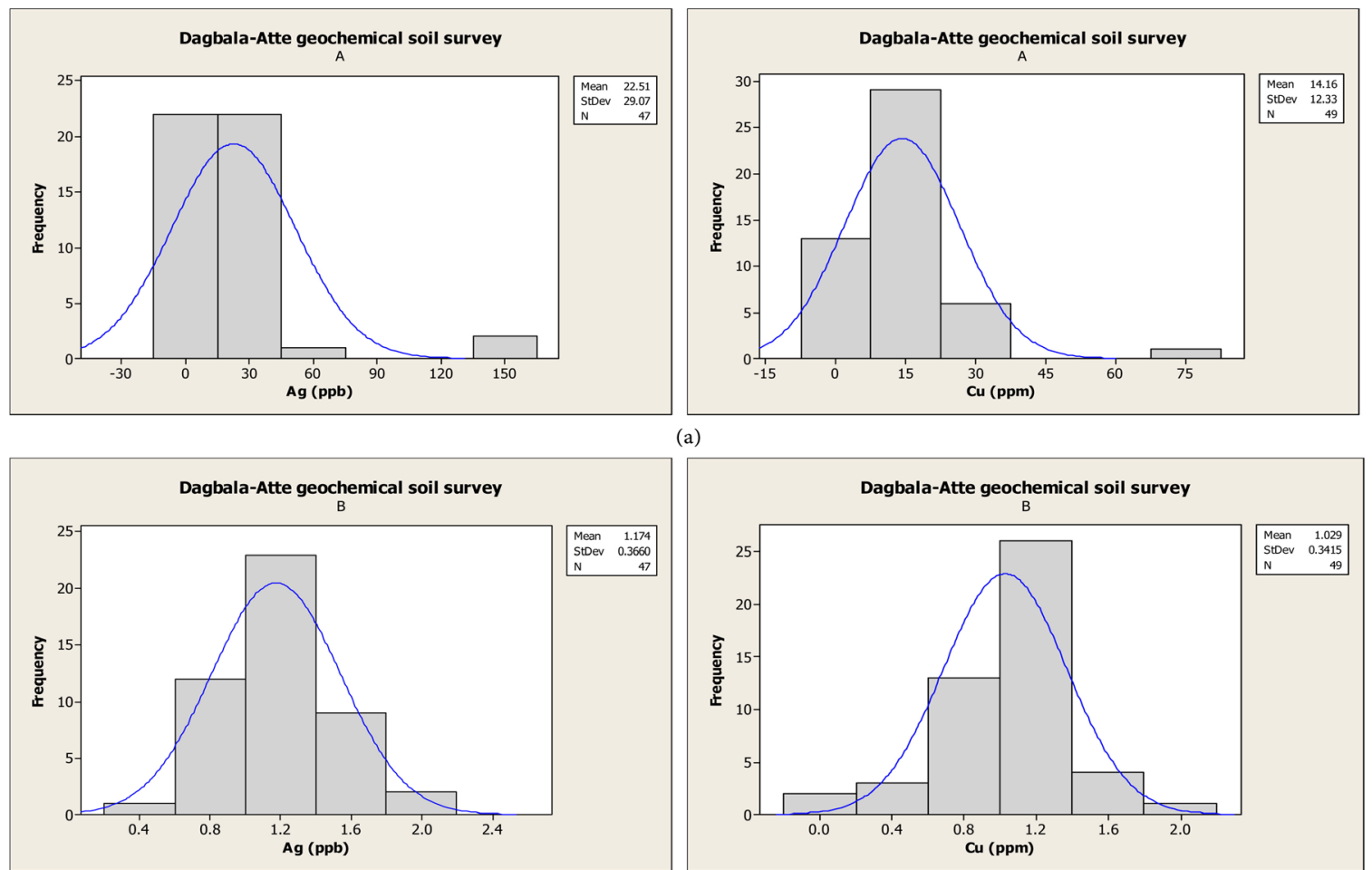

(b)

Figure 4. Histograms of (a) Raw Concentrations and (b) Logarithmically Transformed Concentrations of Ag and Cuin Soils of Dagbala-Atte District.
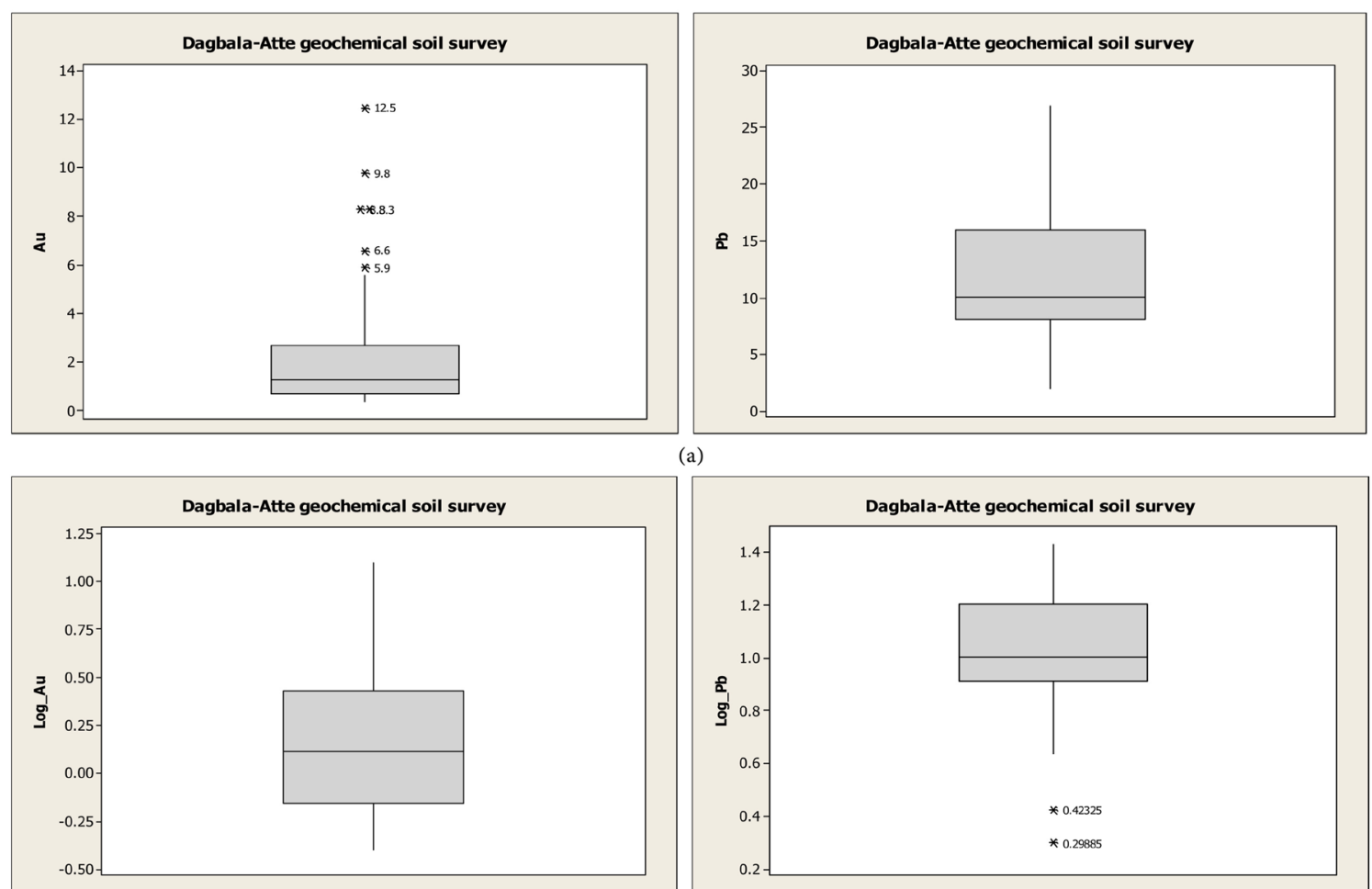

(a)

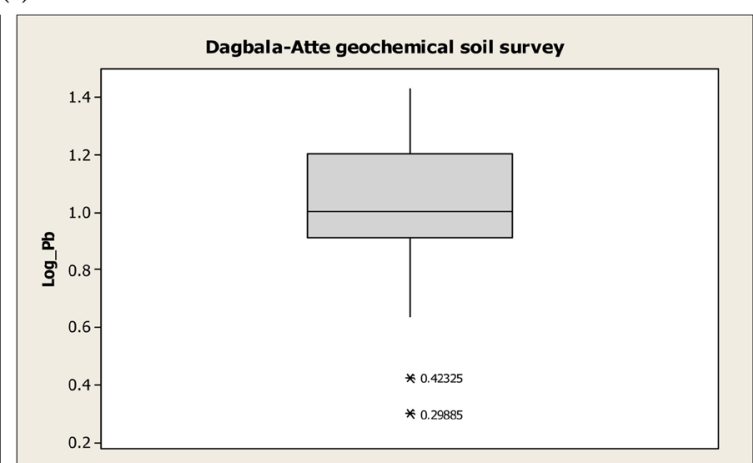

(b)

Figure 5. Boxplots of (a) Raw Concentrations and (b) Logarithmically Transformed Concentrations of Au and $\mathrm{Pb}$ in Soils of Dagbala-Atte District. 
which aided greatly in data analysis. Each of the raw data and logarithmically transformed data plots shows the number of samples that contain anomalous concentrations of elements, called outlier values in the box plots (Figure 5(a) and Figure 5(b)).

\subsection{Correlation Matrix}

Multivariate statistical analysis, which involved correlation matrix and factor analysis, was conducted on ten elements, namely, $\mathrm{Ag}, \mathrm{As}, \mathrm{Au}, \mathrm{Cu}, \mathrm{Fe}, \mathrm{Hg}, \mathrm{Mn}$, $\mathrm{Pb}, \mathrm{Sb}$ and $\mathrm{Zn}$. Cadmium (Cd), having too many censored data (i.e. values below analytical detection limit, DL), was excluded from this analysis [32]. For other elements such as $\mathrm{Ag}, \mathrm{Au}, \mathrm{Hg}$ and $\mathrm{Sb}$ that contain few censored data, values equal to $66 \%$ of their DLs were substituted [32] for the computation of correlation matrix and factor analysis. Table 3 shows the correlation matrix of the elements of interest in the Dagbala-Atte soil geochemical data. The matrix of simple correlation coefficients shows a fairly strong positive correlation between most metals and weak negative correlation between others. It was observed that all the correlation coefficients between metals were significant at $95 \%$ confidence level and above. The best correlation $(\mathrm{r} \geq 0.75)$ occurs between $\mathrm{Cu}-\mathrm{Fe}$ and Fe-Zn, very good correlation $(0.65 \leq \mathrm{r}<0.75)$ exists between $\mathrm{Fe}-\mathrm{Pb}$ and $\mathrm{Hg}-\mathrm{Pb}$, good correlation $(0.55 \leq \mathrm{r}<0.65)$ occurs between each of Ag- $\mathrm{Zn}, \mathrm{As}-\mathrm{Cu}$, As-Fe, As-Sb, $\mathrm{Cu}-\mathrm{Zn}$ and $\mathrm{Mn}-\mathrm{Pb}$; and fairly good correlation $(0.35 \leq \mathrm{r}<0.55)$ exist between $\mathrm{Ag}-\mathrm{Fe}$, Ag-Hg, Ag-Mn, Ag-Pb, Ag-Sb, As-Au, As- $\mathrm{Pb}, \mathrm{As}-\mathrm{Zn}, \mathrm{Cu}-\mathrm{Pb}, \mathrm{Cu}-\mathrm{Sb}$, Fe-Hg, Fe-Mn, Fe-Sb, Hg-Zn, Mn-Zn and Sb-Zn.

\subsection{Factor Analysis}

Table 4(a) is the rotated varimax factor matrix. The factor solutions provided information on eigenvalues (the amount of the total data explained by each model) and communalities (the amount of the total variability of each element explained in a given factor model) for the factor model obtained. The factor matrix

Table 3. Pearson correlation matrix of the elements for log-data of soils in Dagbala-Atte district.

\begin{tabular}{ccccccccccc}
\hline & $\mathrm{Ag}$ & $\mathrm{As}$ & $\mathrm{Au}$ & $\mathrm{Cu}$ & $\mathrm{Fe}$ & $\mathrm{Hg}$ & $\mathrm{Mn}$ & $\mathrm{Pb}$ & $\mathrm{Sb}$ & $\mathrm{Zn}$ \\
\hline $\mathrm{Ag}$ & 1 & & & & & & & & & \\
$\mathrm{As}$ & 0.291 & 1 & & & & & & & & \\
$\mathrm{Au}$ & -0.104 & 0.381 & 1 & & & & & & & \\
$\mathrm{Cu}$ & 0.250 & 0.609 & 0.223 & 1 & & & & & & \\
$\mathrm{Fe}$ & 0.471 & 0.619 & 0.286 & 0.795 & 1 & & & & & \\
$\mathrm{Hg}$ & 0.434 & 0.264 & 0.010 & 0.213 & 0.457 & 1 & & & & \\
$\mathrm{Mn}$ & 0.376 & -0.114 & -0.159 & 0.295 & 0.442 & 0.307 & 1 & & & \\
$\mathrm{~Pb}$ & 0.531 & 0.362 & 0.078 & 0.443 & 0.695 & 0.658 & 0.580 & 1 & & \\
$\mathrm{Sb}$ & 0.511 & 0.589 & -0.088 & 0.351 & 0.432 & 0.143 & 0.043 & 0.149 & 1 & \\
$\mathrm{Zn}$ & 0.642 & 0.434 & 0.062 & 0.631 & 0.792 & 0.389 & 0.513 & 0.669 & 0.483 & 1 \\
\hline
\end{tabular}


Table 4. (a). Varimax rotated factor loadings and communalities for log-data of soils in Dagbala-Atte district. (b). Element associations of the three-factor model.

(a)

\begin{tabular}{ccccc}
\hline Variable & Factor 1 & Factor 2 & Factor 3 & Communality \\
\hline $\mathrm{Ag}$ & 0.761 & -0.394 & -0.264 & 0.804 \\
$\mathrm{As}$ & 0.609 & 0.660 & -0.127 & 0.822 \\
$\mathrm{Au}$ & 0.213 & 0.591 & 0.573 & 0.724 \\
$\mathrm{Cu}$ & 0.604 & 0.510 & -0.068 & 0.630 \\
$\mathrm{Fe}$ & 0.859 & 0.190 & 0.214 & 0.819 \\
$\mathrm{Hg}$ & 0.517 & -0.343 & 0.409 & 0.552 \\
$\mathrm{Mn}$ & 0.202 & -0.844 & 0.026 & 0.753 \\
$\mathrm{~Pb}$ & 0.730 & -0.377 & 0.414 & 0.847 \\
$\mathrm{Sb}$ & 0.682 & 0.124 & -0.586 & 0.823 \\
$\mathrm{Zn}$ & 0.810 & -0.199 & -0.132 & 0.713 \\
Variance & 4.0590 & 2.2637 & 1.1642 & 7.4869 \\
$\%$ Var & 0.406 & 0.226 & 0.116 & 0.749 \\
\hline
\end{tabular}

(b)

\begin{tabular}{ccc}
\hline Factor & Elements & Eigen Value (\%) \\
\hline R-1 & Fe-Zn-Ag-Pb-Sb-As-Cu-Hg & 40.6 \\
R-2 & As-Au-Cu & 22.6 \\
R-3 & Au-Hg-Pb & 11.6 \\
\hline
\end{tabular}

(Table 4(a)) gave a three-factor model presented in Table 4(b). The total explained variance of the three-factor model is $74.9 \%$ (Table 4(a)). Table 4(a) also shows that each factor consists of significant contributions from certain variables and less important to negligible contributions from others. In summary, Factor R-1 has been deduced to be a Fe-Zn-Ag-Pb-Sb-As-Cu-Hg factor, Factor R-2, an $\mathrm{As}-\mathrm{Au}-\mathrm{Cu}$ factor and Factor R-3, a Au-Hg-Pb factor.

Factor R-1 is the most pronounced and accounts for $40.6 \%$ of the three-factor model in the area. It is interpreted to be probably a base metal $(\mathrm{Zn}, \mathrm{Pb}$ and $\mathrm{Cu})$ mineralization with which $\mathrm{Fe}$, possibly in form of pyrite or pyrrhotite, is associated and $\mathrm{Ag}$ that is normally associated with $\mathrm{Pb}$, probably on account of their close ionic radii. The occurrence of $\mathrm{Sb}$, $\mathrm{As}$ and $\mathrm{Hg}$, which are mobile under acidic, oxidizing soil conditions, in the base metal association suggests they can serve as pathfinder elements for these base metals [25] [33]. Factor R-2 also accounts for $22.6 \%$ of the model variance and was interpreted mainly as a gold mineralization factor with which $\mathrm{Cu}$ mineralization is associated and for which also the associated As can serve as a pathfinder element [33]. The high negative loading of $\mathrm{Mn}$ in this factor suggests that $\mathrm{Mn}$ is antipathetically related with this $\mathrm{Au}-\mathrm{Cu}$ mineralization. Also, fairly high negative loading of $\mathrm{Ag}$ in this factor is a pointer to the fact that $\mathrm{Ag}$ mineralization does not associate with Au mineralization in this district, contrary to the common scenario. An implication of this is 
that the lithology that contains the base metal mineralization is different from the one that hosts the Au-Cu mineralization in the district. Factor R-3, which accounts for $11.6 \%$ of the model variance, has been interpreted as probably indicating a limited $\mathrm{Hg}$ mineralization with which $\mathrm{Pb}$ and $\mathrm{Au}$ are associated. The comparatively high negative loading of $\mathrm{Sb}$ in this factor suggests that the probable $\mathrm{Hg}$ mineralization might not be present in the same lithology that contains the base metal mineralization in Factor 1.

\subsection{Geochemical Distribution of the Elements in Soils of Dagbala-Atte District}

The geochemical distribution maps of the elements in the soils of the district have been employed to explain the distribution of the various elements in the soils of the study area. Examples of the geochemical distribution maps of the elements in the district are presented in Figure 6. To ensure that the anomalous sites, selected on the basis of the threshold values fixed for the elements, are meaningful these threshold values were compared with the background concentrations of selected trace elements in the world's soils (Table 5) [25] [33]. Where the concentration of any element in an anomalous site is lower than the average world soil's background value (Table 5) such an anomalous site was considered insignificant. The geological map of the study area was superimposed on the soil sample sites map (Figure 3 ) in order to link the distribution of the elements in the in situ soil of the district with their possible lithologic sources.

Ag has been detected in forty-seven samples, being present below the lower limit of detection of $2 \mathrm{ppb}$ only in two samples. Ag concentrations range in the

Table 5. Background concentration of the analyzed trace elements in soils and utility in geochemical exploration. (Largely after Levinson, 1980 and Rose et al., 1991).

\begin{tabular}{|c|c|c|c|}
\hline Elements & $\begin{array}{c}\text { Background } \\
\text { Concentration in } \\
\text { Soils (ppm) }\end{array}$ & Surficial Mobility & Use in Exploration \\
\hline $\mathrm{Ag}^{*}$ & 100 & High, Mn scavenged & - \\
\hline As & 10 & Mobile, Fe scavenged & Pathfinder especially for $\mathrm{Au}$ \\
\hline $\mathrm{Au}^{*}$ & 1 & Low & Au deposits \\
\hline $\mathrm{Cd}$ & 0.1 & High & Pathfinder for Zn deposits \\
\hline $\mathrm{Cu}$ & 15 & $\mathrm{pH}>5$ low, else moderate & Most surveys \\
\hline $\mathrm{Fe}$ & & & - \\
\hline $\mathrm{Hg}^{*}$ & 50 & High & Wide use as pathfinder \\
\hline $\mathrm{Mn}$ & 300 & Moderate, high at low $\mathrm{pH}$ & Scavenges Co, Zn, Ag \\
\hline $\mathrm{Pb}$ & 15 & Low & Wide use \\
\hline $\mathrm{Sb}$ & 1 & Low & Pathfinder \\
\hline $\mathrm{Zn}$ & 35 & & - \\
\hline
\end{tabular}

${ }^{*}$ Unit of concentration in ppb. 
soils of the study area between 3 and $155 \mathrm{ppb}$, with a mean of $22.51 \mathrm{ppb}$. The element therefore can be said to be fairly widely distributed in the soil of the study area. The threshold value computed for Ag in the District is $43 \mathrm{ppb}$; hence three anomalous values exist at sites DPS15 (58 ppm), DPS34 (155 ppm) and DPS38 (140 ppm). These anomalous soil sites are underlain by granitic gneiss in DPS15 and quartz-biotite schist in DPS34 and DPS38 (Figure 3). When the Ag concentrations of the anomalous sites are compared with the background concentration of Ag in crustal soils (Table 5), only two anomalous sites (DPS34 and DPS38) have values above the background and thus considered significant. The distribution map of silver tends to define an anomalous silver northwest distribution trend. On the basis of good correlation of $\mathrm{Ag}$ with $\mathrm{Zn}$ and $\mathrm{Cu}$ coupled with its fairly good correlation with $\mathrm{Fe}, \mathrm{Hg}, \mathrm{Mn}, \mathrm{Pb}$ and $\mathrm{Sb}$, which are all present in the Factor R-1 it is reasonable to infer that Ag is associated with the suspected $\mathrm{Cu}-\mathrm{Pb}-\mathrm{Zn}$ mineralization in the district. The negative loading of Ag in Factor-R2 (Table 4(a)), i.e. the Au factor, suggests that Ag and Au do not occur in the same mineralization type in the district.

As was detected in 48 samples where its values ranged from 0.1 to 214.5. The mean of As in the soils of the district is $5.95 \mathrm{ppm}$; and the computed threshold value is $10.8 \mathrm{ppm}$. With this threshold value, there exist two anomalous soil sites at DPS11 and DPS38, which are underlain by silicified sheared rock and garnet-biotite schist, respectively (Figure 3). In the north-central part of As distribution map, there is a strong anomalous region which lies over the silicified sheared rock. When the mean value of As in this area is compared with its background concentration in the earth's soils (Table 5), the As concentrations in this area are fairly low. Thus, the anomalous values recorded may not be associated with any concentration of arsenic minerals. However, they may be a pointer to the presence of sulphide deposits, with which some Au and traces of As are associated. The fairly good to very good correlation of $\mathrm{As}$ with $\mathrm{Cu}, \mathrm{Fe}$ and $\mathrm{Sb}$ (Table 3) strongly suggests the presence of sulphide mineralization in the study area. The occurrence of As in Factors 1 and 2 indicates that As can serve as a pathfinder element for both the suspected $\mathrm{Cu}-\mathrm{Pb}-\mathrm{Zn}-\mathrm{Ag}$ mineralization and $\mathrm{Au}-\mathrm{Cu}$ mineralization in this district.

$\mathrm{Au}$ was detected in forty-two of the forty-nine samples employed for this study and it occurred below the detection limit of $0.2 \mathrm{ppb}$ in other seven samples. Au geochemical distribution in the soils of the district is given in Figure 6(a). Au ranges in concentrations from 0.4 to $12.5 \mathrm{ppb}$ with a mean of $2.5 \mathrm{ppb}$. With the threshold value of $5.6 \mathrm{ppb}$ selected for $\mathrm{Au}$, six anomalous values occur at sites DPS7 (8.3 ppb), DPS11 (12.5 ppb), DPS15 (9.8 ppb), DPS18 (8.3 ppb), DPS30 (6.6 ppb) and DPS43 (5.9 ppb). These sites are underlain by quartz-biotite schist (DPS7), silicified sheared rock (DPS11), granitic gneiss (DPS15, DPS30, DPS43) and mica schist (DPS18) (Figure 3). Au distribution map indicates that $\mathrm{Au}$ forms the strongest anomaly in the north-central part of the district. This anomaly has a near ellipsoidal shape extending in the NE-SW 


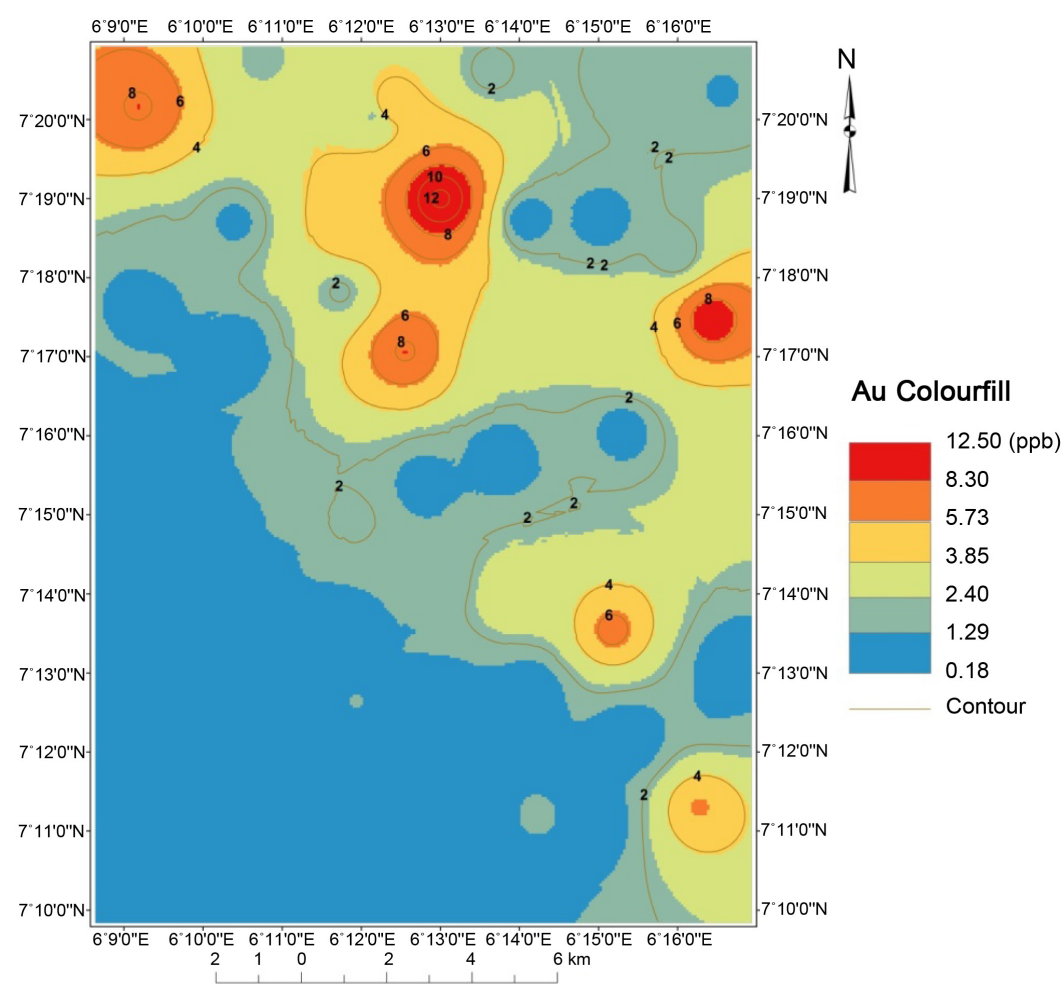

(a)

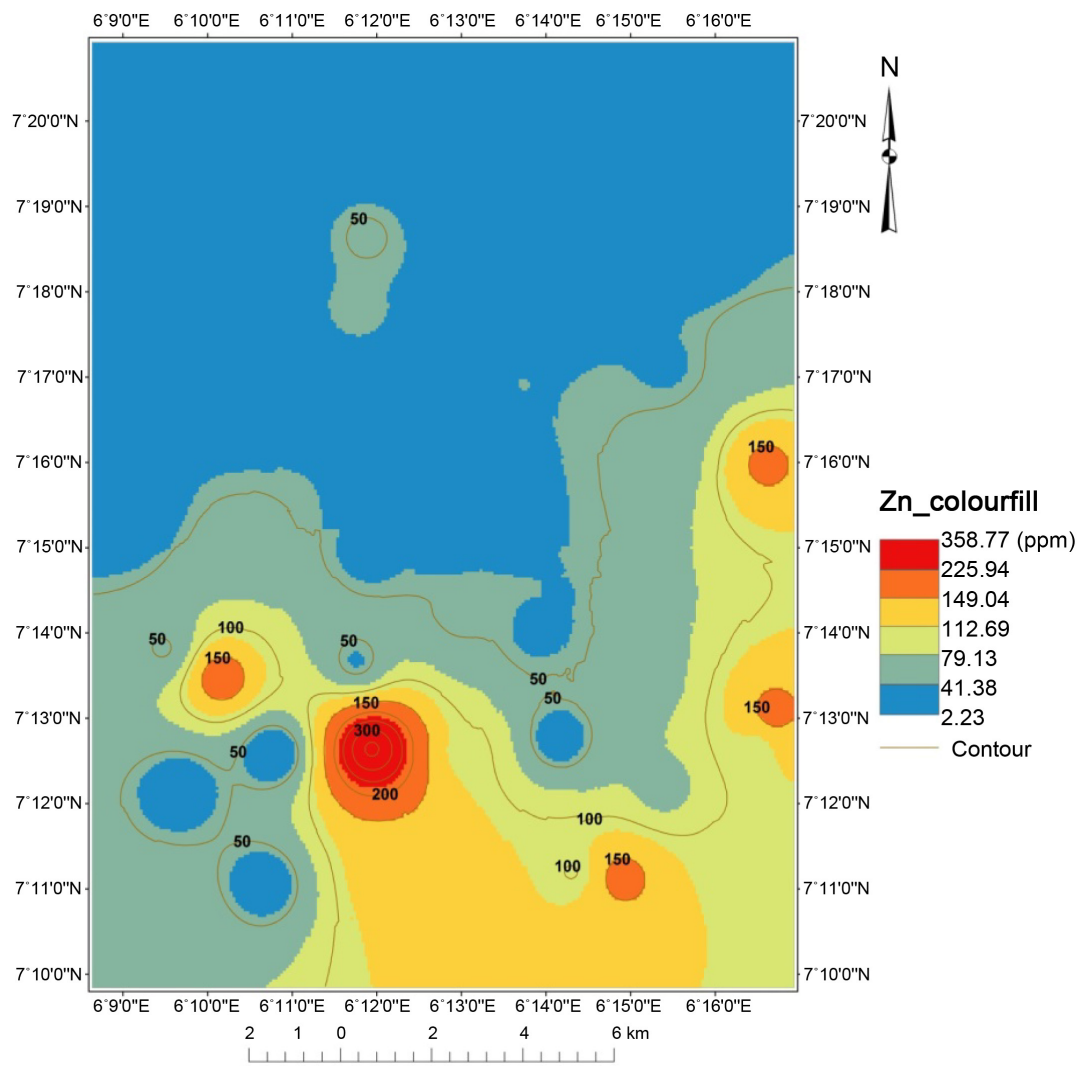

(b)

Figure 6. Geochemical Distribution Maps of (a) Au and (b) $\mathrm{Zn}$ in the soils of Dagbala-Atte District. 
direction. In this north-central area, the strong anomalous sites of As and $\mathrm{Au}$ tend to overlap. Compared with the background concentration of $\mathrm{Au}$ in earth soils (Table 5), the concentration of Au in the soils of the area is generally very high, especially at the anomalous sites. The higher values of $\mathrm{Au}$ in the anomalous sites compared with the average earth's soil value suggest the occurrence of $\mathrm{Au}$ mineralization in parts of the study area. This coupled with the observed correlation of $\mathrm{Au}$ with $\mathrm{As}$ and the association of Au with Factors R-2 and R-3 supports the inference of $\mathrm{Au}-\mathrm{Cu}$ mineralization in the silicified sheared rock, where the anomalous site recorded the highest value of $12,5 \mathrm{ppb}$ of $\mathrm{Au}$, and of $\mathrm{Au}-\mathrm{Hg}-\mathrm{Pb}$ mineralization in the granitic gneiss of Dagbala-Atte District.

$\mathrm{Cu}$ is widely distributed in the study area being detected in all the samples in concentrations ranging from 1.32 to $78.9 \mathrm{ppm}$ with a mean of $14.2 \mathrm{ppm}$. With the threshold value of $33.2 \mathrm{ppm}$, only one anomalous value of copper exists at sample site DPS11 that is underlain by silicified sheared rock (Figure 3). The distribution map for $\mathrm{Cu}$ shows a strong anomalous area of $\mathrm{Cu}$ that coincides with that of As and Au. Compared with the background concentration of $\mathrm{Cu}$ (15 $\mathrm{ppm}$ ) in soils (Table 5), the concentration of copper (78.9 ppm) in the soils of the study area is high. Therefore, the anomalous value is probably due to mineralization. Also, the relatively high correlation of copper with $\mathrm{Fe}, \mathrm{As}, \mathrm{Zn}, \mathrm{Pb}$ and $\mathrm{Sb}$ (Table 3) and the association of copper with the trace elements that constitute Factors R-1 and R-2 (Table 4(a) \& Table 4(b)) supports strongly the presence of $\mathrm{Cu}$ not only in the suspected $\mathrm{Cu}-\mathrm{Pb}-\mathrm{Zn}-\mathrm{Ag}$ mineralization, which element distribution map suggests is located on the quartz-biotite schist, but also in the Au-Cu mineralization based on the silicified sheared rock of the district.

$\mathrm{Hg}$ has been detected in 48 of the 49 samples used for this study. Its values range from 6 to $109 \mathrm{ppb}$ with mean content of $22.6 \mathrm{ppb}$. The selected threshold for mercury is $50 \mathrm{ppb}$. There are two anomalous values for mercury in the study area at site DPS12 (109 ppb) that is underlain by granitic gneiss (Figure 3). The distribution map shows a strong anomalous area with near ellipsoidal shape in the northern part of the area at DPS12 underlain by the granitic gneiss. Compared with its background concentration in soils $(50 \mathrm{ppb})$ (Table 5), the concentration of mercury in the study area is moderate. The paucity of anomalous values probably suggests highly localized concentration of $\mathrm{Hg}$ in the area such as in site DPS 12 located on granite gneiss. The relatively high correlation of $\mathrm{Hg}$ with $\mathrm{Pb}, \mathrm{Ag}, \mathrm{Fe}$ and $\mathrm{Zn}$, as well as the association of $\mathrm{Hg}$ with the elements in Factors R-1 and R-3 (Table 4) suggests the element could serve as a pathfinder element for the suspected $\mathrm{Cu}-\mathrm{Pb}-\mathrm{Zn}-\mathrm{Ag}$ mineralization but the possibility of localized minor $\mathrm{Hg}-\mathrm{Pb}-\mathrm{Au}$ mineralization cannot be ruled out.

All the samples analyzed contain $\mathrm{Pb}$ in concentrations that range from 1.99 to $26.94 \mathrm{ppm}$ with a mean of $11.55 \mathrm{ppm}$. With the selected threshold of $23.03 \mathrm{ppm}$, two anomalous values occur at sample sites DPS15 (24.99 ppm) and DPS46 (26.94 ppm). These sites of anomalous values are underlain by granitic gneiss (Figure 3) and are restricted to the eastern area of the district. Compared with 
the background concentration of $\mathrm{Pb}(15 \mathrm{ppm})$ in the crustal soils (Table 5) the mean $\mathrm{Pb}$ concentration in the soils of Dagbala-Atte District is high. This indicates that there might be lead mineralization in the study area. Also the very good to fairly good correlation of $\mathrm{Pb}$ with $\mathrm{Fe}, \mathrm{Hg}, \mathrm{Mn}, \mathrm{Ag}$, $\mathrm{As}$ and $\mathrm{Cu}$, as well as its association with the elements in Factors R-1 and R-3 supports the association of $\mathrm{Pb}$ with the suspected $\mathrm{Cu}-\mathrm{Pb}-\mathrm{Zn}-\mathrm{Ag}$ mineralization and its presence in the minor Hg-bearing mineralization in the study area.

$\mathrm{Sb}$ has a fairly wide distribution in the study area and is present below the lower detection limit in eight of the samples. The detected values range from 0.02 to $0.38 \mathrm{ppm}$ with a mean value of $0.07 \mathrm{ppm}$. The selected threshold value of $0.11 \mathrm{ppm}$ indicated five anomalous values at sites DPS29 (0.38), DPS34 (0.23), DPS35 (0.22), DPS38 (0.34) and DPS47 (0.24). These anomalous sites are all distributed in the southern part of the district and lie within the quartz biotite schist, except site DPS29 that is within the granite of the district (Figure 3). The generally low concentration of $\mathrm{Sb}$ in the study area may be due to lack of $\mathrm{Sb}$ mineral or stibnite in the study area. Good correlation of $\mathrm{Sb}$ with As and its fairly good correlation with $\mathrm{Ag}, \mathrm{Cu}, \mathrm{Fe}$ and $\mathrm{Zn}$, as well as its association with the elements in Factor R-1 probably reflect its presence as a minor trace element in the suspected $\mathrm{Cu}-\mathrm{Pb}-\mathrm{Zn}-\mathrm{Ag}$ mineralization and its suitability as a pathfinder element for the mineralization in the district. The high negative loading of $\mathrm{Sb}$ in Factor R-3, unlike in the case of Factor R-1, probably indicates that the source of the Hg-bearing association in the former (Factor R-3) differs from the source of the suspected $\mathrm{Cu}-\mathrm{Pb}-\mathrm{Zn}-\mathrm{Ag}$ mineralization associated with the latter (Factor $\mathrm{R}-1)$.

The distribution of $\mathrm{Zn}$ in the soils of the District is shown in Figure 6(b). The concentrations of zinc in the soils of this district range from 2.2 to $358.8 \mathrm{ppm}$ with a mean of $36.9 \mathrm{ppm}$. The selected threshold of $167.7 \mathrm{ppm}$ revealed two anomalous values at sites DPS34 (181.4 ppm) and DPS38 (358.8 ppm). Quartz-biotite schist (Figure 3) underlies the area that yielded the anomalous zinc concentrations. The strong anomalous area for $\mathrm{Zn}$ falls in the south-central part of the district. However, the $\mathrm{Zn}$ values in the study area are low in comparison with the background concentration of $\mathrm{Zn}$ in soils (Table 5). Nevertheless, the high correlation of $\mathrm{Zn}$ with $\mathrm{Pb}, \mathrm{Ag}$ and $\mathrm{Cu}$ (Table 3), tends to confirm the presence of $\mathrm{Zn}$ in the suspected $\mathrm{Cu}-\mathrm{Pb}-\mathrm{Zn}-\mathrm{Ag}$ mineralization in the quartz-biotite schist of Dagbala-Atte District.

\section{Summary and Conclusions}

Geochemical soil survey for base and precious metals was undertaken in Dagbala-Atte District by sampling residual soil from 49 sites in a grid pattern. The forty nine soil samples were analyzed for eleven elements comprising base metals $(\mathrm{Cu}, \mathrm{Pb}$ and $\mathrm{Zn}$ ), precious metals ( $\mathrm{Au}$ and $\mathrm{Ag}$ ) and others including $\mathrm{As}, \mathrm{Cd}, \mathrm{Fe}$, $\mathrm{Hg}, \mathrm{Mn}$ and $\mathrm{Sb}$ commonly associated with the base and precious metals. Statistical analysis of the geochemical data generated involving correlation matrix and 
factor analysis enabled recognition of three major groups of elemental association or factors, viz, $\mathrm{Fe}-\mathrm{Zn}-\mathrm{Ag}-\mathrm{Pb}-\mathrm{Sb}-\mathrm{As}-\mathrm{Cu}-\mathrm{Hg}$ factor (F1), As- $\mathrm{Au}-\mathrm{Cu}$ factor (F2) and $\mathrm{Au}-\mathrm{Hg}-\mathrm{Pb}$ factor (F3). On account of high correlation coefficients between metals (Table 3) and high factor loadings of individual elements (Table 4(a) \& Table 4(b)), three factor models were interpreted in terms of probable mineralization as follows: $\mathrm{F} 1$ is interpreted as a significant $\mathrm{Cu}-\mathrm{Pb}-\mathrm{Zn}-\mathrm{Ag}$ mineralization; $\mathrm{F} 2$ as moderately strong $\mathrm{Au}-\mathrm{Cu}$ mineralization and $\mathrm{F} 3$ as a minor $\mathrm{Hg}$-bearing $\mathrm{Au}-\mathrm{Pb}$ mineralization in the district.

By using the threshold values as cut-off points, the anomalous values for the various elements at the sample sites were determined. Superimposing the geochemical distribution maps of the various elements in the residual soils on the geological map of the district enables identification of the possible lithologic sources of these anomalous values [26] [27]. Hence, the anomalous values and the suspected mineralization types in the Dagbala-Atte District are linked with different rock types as follows:

1) The $\mathrm{Cu}-\mathrm{Pb}-\mathrm{Zn}-\mathrm{Ag}$ mineralization is inferred to be located on quartz-biotite schist that underlies the southwestern part of the district around Sasaro and Egbigele.

2) The $\mathrm{Au}-\mathrm{Cu}$ mineralization is based on the silicified sheared rock that occupies the northern and southern parts of the district around Dagbala and Atte.

3) Minor Hg-bearing $\mathrm{Au}-\mathrm{Pb}$ mineralization in the granitic gneiss that underlies the northeastern and eastern part of the district around Erurhu and Atte.

The association of some trace elements such as $\mathrm{As}, \mathrm{Cd}, \mathrm{Hg}$ and $\mathrm{Sb}$ with the suspected mineralization suggests that they can be used as pathfinders on account of their relatively high concentration and mobility in the acidic, oxidizing soil environment [25] [33]. It would appear that As would be a suitable pathfinder for the suspected $\mathrm{Au}-\mathrm{Cu}$ mineralization and $\mathrm{As}, \mathrm{Hg}$ and $\mathrm{Sb}$ for the suspected $\mathrm{Cu}-\mathrm{Pb}-\mathrm{Zn}-\mathrm{Ag}$ mineralization. Based on the foregoing linkage of the inferred mineralization types with some rock types in the study area, the lithogeochemical survey of the area is logically recommended.

\section{Conflicts of Interest}

The author declares no conflicts of interest regarding the publication of this paper.

\section{References}

[1] Garba, I. (1985) The Geology and Stream Sediment Prospecting for Gold, Sheet 225, Isanlu, Kwara State. Unpublished M.Sc. Thesis, Ahmadu Bello University, Zaria.

[2] Woakes, M., Rahaman, M.A. and Ajibade, A.C. (1987) Some Metallogenetic Features of the Nigerian Basement. Journal of African Earth Sciences, 6, 54-64.

[3] Adekoya, J.A. (1988) Precambrian Iron Formation of Northwestern Nigeria. In: Precambrian Geology of Nigeria, GSN Publication, Kaduna, Nigeria, 195-210.

[4] Garba, I. (2002) Late Pan African Tectonics and Origin of Gold Mineralization and Rare-Metal Pegmatites in the Kushaka Schist Belt, Northwestern Nigeria. Journal of 
Mining and Geology, 38, 1-12.

[5] Adepoju, M.O. and Adekoya, J.A. (2008) Statistical Analysis of Reconnaissance Geochemical Data from Orle District, Southwestern Nigeria. Global Journal of Geological Science, 6, 63-74.

[6] Adepoju, M.O. and Adekoya, J.A. (2011) Reconnaissance Geochemical Study of a Part of Igarra Schist Belt, Southwestern Nigeria. Ife Journal of Science, 13, 75-92.

[7] Odokuma, A.O. and Adekoya, J.A. (2013) Factor Analysis of Stream Sediment Geochemical Data from Onyami Drainage System, Southwestern Nigeria. International Journal of Geomatics and Geosciences, 4, 656-661.

[8] Adepoju, M.O. (2018) Heavy Metal Distribution and Pollution Evaluation in Soils of Dagbala-Atte District, Southwestern Nigeria. Journal of Geography, Environment and Earth Science International, 18, 1-17.

[9] Adepoju, M.O. and Adekoya, J.A. (2013) Heavy Metal Distribution and Assessment in Stream Sediments of River Orle, Southwestern Nigeria. Arabian Journal of Geosciences, 7, 743-756. https://doi.org/10.1007/s12517-013-0845-1

[10] Thomson, I. and Brim, R.J.P. (1976) A geoquimica no Projeto Geofisico Brasil-Canada: umaavaliacaopreliminar dos resultados; Anais do I Sem. Bras. sob. Tec. Explor. em Geol., Pocos de Caldas, 103-104.

[11] Worthington, J.E., Jones, E.M. and Kiff, I.T. (1976) Techniques of Geochemical Exploration in the Southeast Piedmont of the United States. Journal of Geochemical Exploration, 6, 279-295.

[12] Cox, R. (1974) Geochemical Soil Surveys in Exploration for Nickel-Copper Sulphides at Pioneer, near Norseman, Western Australia. In: Elliott, I.L. and Fletcher, W.K., Eds., Geochemical Exploration, Elsevier Publ. Co., Amsterdam, 437-460.

[13] Reedman, J.H. (1974) Residual Soil Geochemistry in the Discovery and Evaluation of the Butirikucarbonatite, Southeast Uganda. Inst. Min. Met. Trans., 83-B, 1-12.

[14] Coope, J.A. (1973) Geochemical Prospecting for Porphyry Copper-Type Mineralization-A Review. Journal of Geochemical Exploration, 2, 81-102. https://doi.org/10.1016/0375-6742(73)90008-3

[15] Chakrabarti, A.K. and Solomon, P.J. (1970) A Geochemical Case History of the Rajburi Antimony Prospect, Thailand. Economic Geology, 65, 1006-1007. https://doi.org/10.2113/gsecongeo.65.8.1006

[16] Dada, S.S. (1989) Evolution de la croute continentale au Nord Nigeria U-Pb et de traceursisotopiques $\mathrm{Sr}, \mathrm{Nd}$ et $\mathrm{Pb}$. These Diplome de Doctoral, Univ. der Sci. Tech. Lang, Montpellier, 200.

[17] Hockey, R.D., Sacchi, R., de Graaff, W.P.F.H. and Muotoh, E.O.G. (1986) The Geology of Lokoja-Auchi Area: Explanation of 1:250,000 Sheet 62. Geol. Surv. Nigeria. Bull., No. 39, 71 p.

[18] McCurry, P. (1976) The Geology of the Precambrian to Lower Paleozoic Rocks of Northern Nigeria-A Review. In: Kogbe, C.A., Ed., Geology of Nigeria, Elizabethan, Lagos, 15-59.

[19] Oyawoye, M.O. (1964) The Geology of the Nigerian Basement Complex. Journal of Mining and Geology, 1, 87-102.

[20] Egbuniwe, I.G. and Ocan, O.O. (2004) Selection of Fieldwork Areas for Teaching/Training: Igarra Area as an Example. Proceedings of Field Mapping Standardization Workshop, Ibadan University Press, Ibadan, 79-95.

[21] Odeyemi, I.B. (1988) Lithostratigraphy and Structural Relationships of the Upper Precambrian Metasediments in Igarra Area, Southwestern Nigeria. In: Oluyide, 
P.O., Mbonu, W.C., Ogezi, A.E., Egbuniwe, I.G., Ajibade, A.C. and Umeji, A.C., Eds., Precambrian Geology of Nigeria, Publ. GSN, 111-125.

[22] Odeyemi, I.B. (1977) On the Petrology of the Basement Complex Rocks of Bendel State, Nigeria. Ph.D. Dissertation, University of Ibadan, Ibadan, 239 p.

[23] Odeyemi, I.B. (1976) Preliminary Report on the Field Relationships between the Basement Complex Rocks in Igarra, Midwestern Nigeria. In: Kogbe, C.A., Ed., Geology of Nigeria, Elizabethan Publ. Co. Lagos, Lagos, 59-63.

[24] Adepoju, M.O. (2017) Geological and Geochemical Exploration Studies in Dagbala-Atte District in Igarra Schist Belt, Southwestern Nigeria. Ph.D. Dissertation, FUTA, Nigeria.

[25] Levinson, A.A. (1974) Introduction to Exploration Geochemistry. Applied Publication Limited, Calgary, p. 1965.

[26] Adepoju, M.O., Adekoya, J.A. and Odeyemi, I.B. (2018) Statistical Evaluation of Soil Geochemical Data from Dagbala-Atte District in Igarra Schist Belt, Southwestern Nigeria. Geoinformatics and Geostatistics: An Overview, 6, 4.

[27] Adesiyan, A., Adekoya, A., Akinlua, A. and Torto, N. (2014) Statistical Studies of Soil Geochemical Data from Gbongan-Odeyinka Area, Southwestern Nigeria. Geoinformatics and Geostatistics: An Overview, 2, 1.

[28] Ajayi, T.R. (1981) Statistical Analysis of Stream Sediment Data from the Ife-Ilesha Area of Southwest Nigeria. Journal of Geochemical Exploration, 15, 539-548. https://doi.org/10.1016/0375-6742(81)90085-6

[29] Chapman, R.P. (1978) Evaluation of Some Statistical Methods in Interpreting Multi-Element Geochemical Drainage Data from New Bruswick. Mathematical Geolo$g y$, 10, 195-224. https://doi.org/10.1007/BF01032864

[30] Closs, L.G. (1975) The Role of Factor and Regression Analysis in the Interpretation of Geochemical Reconnaissance Data. Canadian Journal of Earth Sciences, 12, 1316-1330. https://doi.org/10.1139/e75-122

[31] Tukey, J.W. (1977) Exploratory Data Analysis. Addison-Wesley, Boston.

[32] Sadeghi, M., Billay, A. and Carranza, E.J.M. (2015) Analysis and Mapping of Soil Geochemical Anomalies: Implications for Bedrock Mapping and Gold Exploration in Giyani Area, South Africa. Journal of Geochemical Exploration, 154, 180-193. https://doi.org/10.1016/j.gexplo.2014.11.018

[33] Rose, A.W., Hawkes, H.E. and Webb, J.S. (1991) Geochemistry in Mineral Exploration. 3rd Edition, Academic Press, London, 711 p. 